\title{
OTAKU AND THE STRUGGLE FOR IMAGINATION IN JAPAN
}




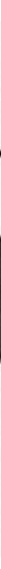




\section{OTAKU AND THE STRUGGLE FOR IMAGINATION \\ Patrick W. Galbraith IN JAPAN}

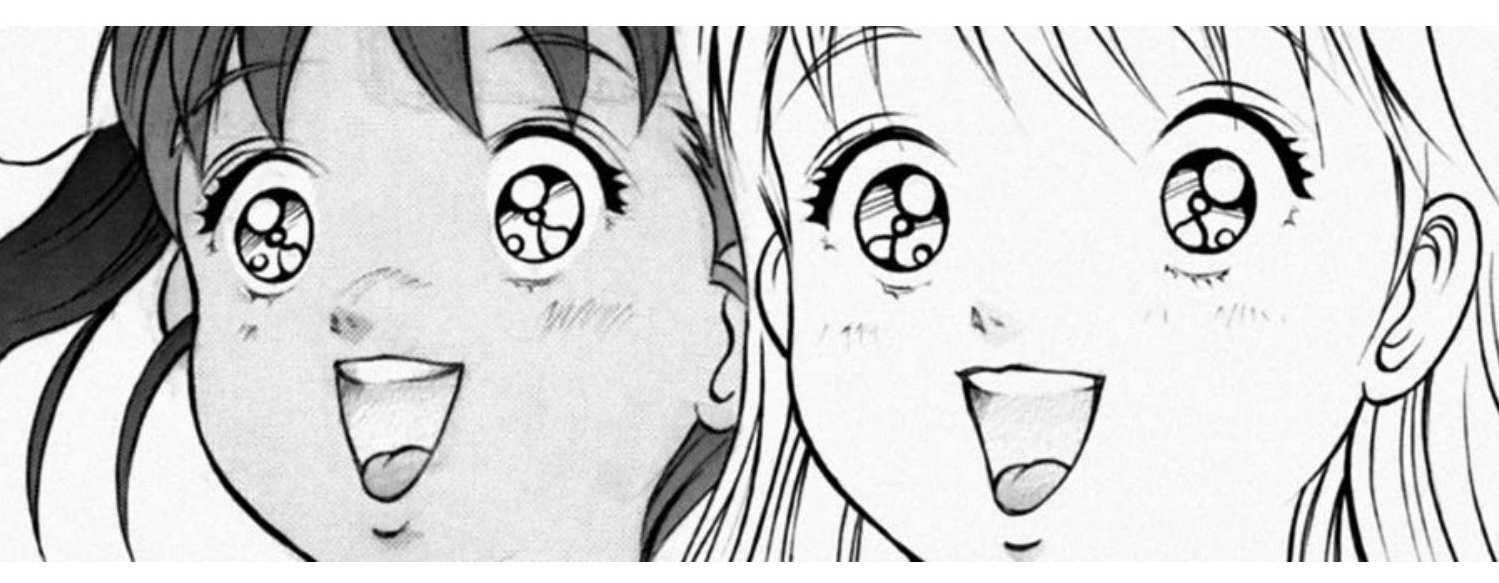


(C) 2019 Duke University Press

All rights reserved

Printed in the United States of America on

acid-free paper $\infty$

Designed by Matthew Tauch

Typeset in Arno Pro by Westchester Book Group

Library of Congress Cataloging-in-Publication Data

Names: Galbraith, Patrick W., author.

Title: Otaku and the struggle for imagination in Japan /

Patrick W. Galbraith.

Description: Durham : Duke University Press, 2019. | Includes bibliographical references and index.

Identifiers: LCCN 2019008724 (print) | LCCN 2019016967 (ebook)

ISBN 9781478007012 (ebook)

ISBN 9781478005094 (hardcover : alk. paper)

ISBN 9781478006299 (pbk. : alk. paper)

Subjects: LCSH: Mass media and culture-Japan. | Fans (Persons) -

Japan. | Popular culture-Japan. | Animated films-

Japan-History and criticism. | Japan—Social life and

customs-21st century.

Classification: LCC P94.65.J3 (ebook) | LCC P94.65.J3 G353 2019

(print) | DDC 306/.10952-dc23

LC record available at https://lccn.loc.gov/2019008724 
IMAGINATION is the key to empathy, and if we're not able to imagine peoples' lives, then our empathy diminishes. Translation is a bridge that serves to enlarge imagination, to connect to the world. We're impoverished without it. PHILIP BOEHM, 2017 
This page intentionally left blank 